InterAção | 131

\title{
REVOLUTIONARY MEDICINE: A RESPONSE TO CORPORATIZING HEALTHCARE IN INDIA
}

Prakash Kona ${ }^{1}$

\section{Abstract}

This article explores Che Guevara's notion of "revolutionary medicine" and how it is imperative to challenge the corporatization of healthcare in a developing nation such as India where millions live under subhuman conditions owing to lack of basic necessities that constitute any definition of a human life. With the corporatization of healthcare the deprivation gets further magnified creating the grounds for a social revolution. The notion of "revolutionary medicine" helps us analyze the role of corporatization of healthcare in furthering the haves-havenots divide, the need for nationalization of healthcare, the possibilities of a social revolution and the role of a revolutionary doctor in changing the order.

Political institutions are formed upon the consideration of what will frequently tend to the good of the whole, although now and then exceptions may occur. Thus it is better in general that a nation

1 Prakash Kona is a writer, teacher and researcher working as Associate Professor at the Department of English Literature, The English and Foreign Languages University (EFLU), Hyderabad, India. He is the author of Conjurer of Nights [poetry: 2012, Waterloo Press, Hove, UK]; Nunc Stans [Creative Non-fiction: 2009, Crossing Chaos enigmatic ink, Ontario, Canada], Pearls of an Unstrung Necklace [Fiction: 2005, Fugue State Press, New York] and Streets that Smell of Dying Roses [Experimental Fiction: 2003, Fugue State Press, New York]. 
132 | InterAção

should have a supreme legislative power, although it may at times be abused. And then, Sir, there is this consideration, that if the abuse be numerous, Nature will rise up, and claiming her original rights, overturn a corrupt political system." James Boswell: Life of Johnson

Key Words: Healthcare. Revolution. Medicine. Doctor. Che Guevara.

\section{Corporate Healthcare}

Walter Benjamin famously concludes his essay "The work of art in the age of mechanical reproduction" with the enigmatic statement, "Communism responds by politicizing art". While fascism conceals politics under an "aesthetic" discourse, communism unmasks politics and shows power relations for what they really are in a fascist society. In the attempt to unmask the vicious character of power, "the specter of communism" will haunt the battlefields where the aesthetic will fight the bitter reality of experience.

How do we define experience other than as lived reality! How do we define reality other than as lived experience! To experience reality is to know the difference between one's immediate situation and what is alternative to the situation. Bourgeois realism accepts the situation for an unchanging fact of life. The experience of reality is to see through the fictitious basis of the so-called fact; to embrace the emotional insights that bridge the gap between what is and what should be; to be intransigent in the face of the violence of what passes for the truth; to allow realization to transform reality; to see the transformation as an everyday fact of life; to use transformation interchangeably with expe- 
InterAção | 133

rience; the politicizing of art is the politicizing of everyday life and the politicizing of experience.

The intellectual is political in a comprehensive sense and not someone who reduces the world to politics. To politicize is to make choices and not to indulge in jargon that through a pre-given method resolves a puzzle the way one does with the Rubik's cube. How do we define the communist intellectual except as Gramsci says, someone who has "worked out and made coherent the principles and the problems raised by the masses in their practical activity" (330). In the same passage Gramsci stretches the point further that only when a philosophical movement comes into contact with what he calls the "simple" by which he means the problems raised by the masses in their practical activity, "does a philosophy become "historical", purify itself of intellectualistic elements of an individual character and become "life". The "intellectualistic elements" are without the character of life because they are not rooted in practical activity or what we call work. The ability to theorize is rooted in the experience of work.

Work is a complex term from breathing to doing a difficult arithmetic problem, swimming or designing a building. There is no work however despicably routine or soul-killing that it does not need imagination. The "corporate market" is not anti-work in principle as much as it is anti-worker; it is guilty of separating work from reality; that there is a reality outside the human effort to be creative and free; as McMurtry makes the point in The Cancer stage of capitalism: "People who must work most of their active hours to earn enough money to live must normally sell their work or service to a corporation or other employer in exchange for wages and salaries. The sale 
of their work is all of the value they have to sell in the corporate market" (49). Their right to imagine or the right to be real is taken away from them. Having lost the reality that creative work promises to bring them into touch with, they live isolated from the "concrete" submitting consciously to free market hallucinations. Karel Kosik in Dialectics of the Concrete calls it the "doctrinaire systematization or the romanticization of routine ideas" (6). Trite and banal notions get packaged and repackaged as original without possessing the essence of originality which is being creative. The lack of freedom is built into the idea - since the idea is about consumption and not about freedom.

Dr. Johnson notes that: "Human experience, which is constantly contradicting theory, is the great test of truth" (Life 238). Theory is the ability to make assumptions about a situation; but such ability has to be preceded by experience that is bound to contradict the theory at any point in time. Theories are static in that sense unless like the legendary Proteus they are able to adapt themselves to the lived nature of experience. Gramsci points out that: "the majority of mankind are philosophers in so far as they engage in practical activity and in their practical activity (or in their guiding lines of conduct) there is implicitly contained a conception of the world, a philosophy" (344).

The theoretical basis of healthcare is that it forms a privileged body of knowledge independent of power relations. That the "treatment" of patients is far more patient-centered in a corporate than in a state-run hospital is the premise on which the latter claim their superiority. The dehumanization of the patient and stripping of individual rights is never spoken about as an issue. It's not knowledge 
that creates a sense of power but pure faith in that kind of knowledge. The statement from Louis Pasteur and the hidden world of microbes illustrates my point. "Referring to Colin's results, which contradicted his own, Pasteur scoffed, "If I take a clod of earth and find anthrax there, that's because it's there; and if, placing the same clod between the hands of M[onsieur] Colin, he doesn't find it, that's because he has made a mistake. One road leads to truth, a thousand to error. Colin always takes one of the latter"' (72). The road that leads to "truth" is just one, while "thousand" lead to error. There is nothing to explain what distinguishes truth from error. There is no definition to back the statement even for a great scientist like Louis Pasteur. The modern hospital is built on a theory of what constitutes knowledge because it has "truth" on its side. An ahistorical truth can never be a scientific one. A truth isolated from social and political contexts is an ideological statement because it is a natural one or a cultural one but never a historical one.

The Hospital X that Orwell talks about in "How the poor die" shows what the reality on the ground is like. Orwell says: "If you are seriously ill and if you are too poor to be treated in your own home, then you must go into hospital, and once there you must put up with harshness and discomfort, just as you would in the army." The "army" and the "hospital" comparison is true with everyone who has the experience of being in a hospital for a certain period of time irrespective of whether it's a private or a public one. In the public hospital you confront the reality of being in a state of want. In the private hospital the good-will and the atmosphere is paid for and thus alienating in its own way. Orwell adds in the same essay: 
136 | InterAção

Hospitals began as a kind of casual ward for lepers and the like to die in, and they continued as places where medical students learned their art on the bodies of the poor. You can still catch a faint suggestion of their history in their characteristically gloomy architecture. I would be far from complaining about the treatment I have received in any English hospital, but I do know that it is a sound instinct that warns people to keep out of hospitals if possible, and especially out of the public wards. Whatever the legal position may be, it is unquestionable that you have far less control over your own treatment, far less certainty that frivolous experiments will not be tried on you, when it is a case of 'accept the discipline or get out'. And it is a great thing to die in your own bed, though it is better still to die in your boots. However great the kindness and the efficiency, in every hospital death there will be some cruel, squalid detail, something perhaps too small to be old but leaving terribly painful memories behind, arising out of the haste, the crowding, the impersonality of a place where every day people are dying among strangers.

While medical students continue to learn "their art on the bodies of the poor," it is the apparent "impersonality" of state-run hospitals, a painful experience you supposedly avoid by going to a corporate hospital. This is not to forget that the latter has all the features of a theatre - sometimes with the settings more than obvious - a mise-en-scene with the doctors and nurses and ward boys etc. into which the patient enters as a necessary component of the performance. Money is the basis of the performance and not method - not blatant self-deception but outright calculatedness.

In his "The Power of Money in Bourgeois society, from Economic and Philosophic Manuscripts of 1844," the young Marx points out that: "By possessing the property of buying everything, by posses- 
sing the property of appropriating all objects, money is thus the object of eminent possession. The universality of its property is the omnipotence of its being. It therefore functions as the almighty being. Money is the pimp between man's need and the object, between his life and his means of life. But that which mediates my life for me, also mediates the existence of other people for me. For me it is the other person" (Tucker 102). The corporate hospital is a financial institution where money is rotated at various levels. Institutions are social products and reproduce the hierarchies of the real world. The corporate hospital is an extension of inequalities of the social world. If corporatization is meant to reach out to the poor it is merely to appropriate their meager resources and not to address the disease whose origins are social as much as political rooted in an economy of powerlessness.

Corporatization of healthcare in India is an American-style institution attempting to be comprehensive in the maximum sense possible. The American conditions are conspicuous by their absence. By American conditions I mean the cultural matrix for an institution to exist; this is not possible in a third world country like India where the relationship between the doctor and a patient is fundamentally an unequal one more so if the patient comes from the exploited classes; the patient is patronized and humiliated and made to rely completely on the doctor for support or "cure"; money is the principal medium that brings together the patient and the doctor - practically you cannot be in a corporate hospital unless you afford it; the relationship therefore is a deeply alienating one similar to the prostitute and a client except that the prostitute is the exploited while the doctor who sells himself is the exploiter. McMurtry says: "The efficiency that 
exists here is the lower ratio of costs to revenues for transnational corporations. This once more is accepted as rational and good. But its implication is again not seen, that it excludes costs to life. On the life scale, this system is very inefficient. How monstrously inefficient we will discover as this diagnosis deepens" (54). Theoretical paradigms that deal with the doctor-patient relationship outside the larger framework of the role of capitalism and ownership are not merely missing the tree for the forest; the tree in this case is without roots and like fantastic trees in fantasy tales stands in the air and shows all signs of a fantastic life without any basis in day-to-day reality.

Bourgeois society brings out that pimp quality of money and the corporate hospitals take the viciousness of the pimp to a whole new level when it comes to the body of the sick person. In a country like India we've to deal directly with the hospital management through money that "mediates my life for me." The Indian patient more often than not does not have the buffer zone of the insurance company to deal with. You pay the money and you get the service. You don't pay the money, you don't. In one of the "Proverbs of Hell," William Blake says: "Prisons are built with stones of Law, Brothels with bricks of Religion." He forgot to add: "Hospitals are made with bodies of the old, the sick and the dying." If sickness is invented for the treatment to become a reality, then, in more ways than one, the standardized treatment anticipates the sickness. Without the existence of the "sick" the treatment is meaningless. The sick person embodies the treatment.

Apart from the fact that the idea of a "cure" is born before the person is in fact ill, a particular body aesthetic is associated with 
corporate healthcare. The aestheticizing of the body is opposed to the politicizing of the same body. The aesthetic body dreads the disease and allows the knowledge of the medical institution to disempower it of all meaning. The political body is suspicious and constantly raises doubts as to the truthfulness of institutional statements pronounced as God-given dictum by the doctors. The aesthetic body submits while the political body resists to the last minute. The aesthetic body allows its humanity to be torn to shreds while it can keep up appearances in tact. The political body damns all appearance, refuses to renounce its humanity and like Johnson will say to the very end: "I will be conquered; I will not capitulate" (972).

The rational, scientific treatment of the disease is integrated with the discourse of care. The 2003 Hindi comedy movie Munna Bhai MBBS aspires to be the spokesperson for the voice of care. "Care" however is an economic and political term and the worst forms of patronage and inequality are disguised under the label of caring. Care is dealt with at a superficial level of being "nice" to people the way it is expected in Walt Disney cartoons and Munna Bhai who is an outsider to the system ends up being a traitor to his class by becoming one with his exploiters. All he wants of them is to care for him. He mouths the very philosophy of the bourgeoisie which is to talk about anything but not his marginality except in vague and sentimental terms. The convenient ending for Munna Bhai is to get married to the doctor's daughter - the very doctor whom he has been at odds with through a great part of the movie. From a potential radical Munna Bhai ends up becoming a full-time reactionary. The body aesthetic that Munna Bhai espouses - its ultimate embodiment 
is the corporate healthcare.

In a neocolonial political economy such as the US where insurance and the individual are connected you have a corporate healthcare system though its inclusiveness is a matter of debate. The first provision of the Health Reform introduced recently by the Obama administration proudly declares:

This Act puts individuals, families and small business owners in control of their health care. It reduces premium costs for millions of working families and small businesses by providing hundreds of billions of dollars in tax relief - the largest middle class tax cut for health care in history. It also reduces what families will have to pay for health care by capping out-of-pocket expenses and requiring preventive care to be fully covered without any out-of-pocket expense. For Americans with insurance coverage who like what they have, they can keep it. Nothing in this act or anywhere in the bill forces anyone to change the insurance they have, period.

It does not say that healthcare is the right of the individual citizen. The devil is in the detail and these reforms significantly mean nothing because they are based on the fact that unless you're insured you get nothing. What do these reforms mean to someone with no means to survive on a day-to-day basis! It's another tactic for getting more customers to the Insurance companies and by extension the hospitals as well.

The much-trumpeted Rajiv Aarogyasri Community Health Insurance Scheme in the Indian state of Andhra Pradesh is basically a corporate-friendly venture that provided much needed oxygen to the 
InterAção | 141

dying hospital industry that put the poor out of the picture. Instead of directly looting from the poor the corporations take from the government that loots the poor. These so-called people-oriented schemes are symptom-addressing devices and do not address the disease of exploitation endemic to this nation.

The corporatization made possible through widespread corruption at every level has reached tyrannical proportions and holds an entire civil society to ransom. The pauperization of the middle classes who are portrayed as the beneficiaries of globalization is achieved in a gradual manner. The plight of those who barely make a living such as migrant workers and other homeless people exposed to the worst forms of pollution can only be imagined. Samuel Johnson says: "I consider that in no government power can be abused long. Mankind will not bear it. If a sovereign oppresses his people to a great degree, they will rise and cut off his head. There is a remedy in human nature against tyranny that will keep us safe under every form of government" (351). Ultimately there is only so much tyranny that mankind will bear. The "remedy in human nature" that Johnson speaks of which is cutting the head of the sovereign is a euphemism for an armed revolution.

\section{Revolutionary Medicine}

In his talk "On Revolutionary Medicine," the doctor-turned-revolutionary Che Guevara says that, "For one to be a revolutionary doctor or to be a revolutionary at all, there must first be a revolution." The "objective" conditions on the ground where irreconcilable contra- 
dictions begin to show have to meet the "subjective" conditions that involve individual or group decisions and strategies to be used for the revolution to be a reality (A Revolutionary Life 553). The closest analogy to what is "objective" is a boiling point situation where the common people are deprived of basic amenities and where the illusions produced by ideological mechanisms such as the media fail to reduce the staggering gap between having and not having; there is a relative dimension to it because globalization produces a feeling of want, a loss of dignity, an awareness of being exploited and humiliated along with an exhilarating sense that "things" must fall apart for life as it is to become what it should be. The viciousness of an order produces a subjective response that is virulent and devastating because it has no place for what is moderate and reasonable. The complexities of individual situations must be borne in mind at all times. Che elaborates on the point while quoting the Second Declaration of Havana in Guerrilla Warfare: A Method when he says: "The subjective conditions in each country, the factors of consciousness, of organization, of leadership, can accelerate or delay revolution, depending on the state of their development. Sooner or later, in each historic epoch, as objective conditions ripen, consciousness is acquired, organization is achieved, leadership arises and revolution is produced".

The argument central to this paper is that the objective conditions along with their contradictions exist in terms of the horrendous poverty and underdevelopment of the villages and the substandard quality of life of the urban poor who exist on the margins of a rather thin globalized mainstream India. According to the website Economy Watch: 
Since its independence, the issue of poverty within India has remained a prevalent concern. According to the common definition of poverty, when a person finds it difficult to meet the minimum requirement of acceptable living standards, he or she is considered poor. Millions of people in India are unable to meet these basic standards, and according to government estimates, in 2007 there were nearly 220.1 million people living below the poverty line. Nearly $21.1 \%$ of the entire rural population and $15 \%$ of the urban population of India exists in this difficult physical and financial predicament.

It is apparently ironic that despite deprivation that involves millions, the subjective conditions Che is talking about are yet to emerge on a mass scale. In Guerrilla Warfare: a method, Che mentions that: "it is not always necessary to wait for all conditions favorable to revolution to be present; the insurrection itself can create them." The conditions for radical change are not always the same as conditions of exploitation; it is essential for them to merge in order for a revolution to be a matter of life and death. In a country like India, religion, caste, language, ethnicity and other divisions work against the coming together of exploited groups with common interests. Globalization irons out those differences and makes visible an invisible enemy.

In submitting to the indignity of globalization through a system of dehumanizing wage slavery the poor have little choice but to embrace the struggle that will recognize their humanity. Given the fundamental importance of healthcare the pinch of the economy on the meager wages of the working classes becomes the straw that'll break the proverbial camel's back. The labor is alienated, the poor are poorer but the fruit of their labor stands in the form of glaring 
144 | InterAção

wealth and the unleashing of productive forces through an ideology popularly termed as globalization.

This is where revolutionary medicine comes into picture. The revolution is an antidote to globalization and its ideologues such as the right-wing economist Jagdish Bhagwati who claim:

1. Far too many among the young see capitalism as a system that cannot address meaningfully questions of social justice...That capitalism may be viewed instead as a system that can paradoxically destroy privilege and open up economic opportunity to the many is a thought that is still uncommon. I often wonder, for example, how many of the young skeptics of capitalism are aware that socialist planning in countries such as India, by replacing markets system wide with bureaucratically determined rations of goods and services, worsened rather than improved unequal access because socialism meant queues that the well-connected and the well-endowed could jump, whereas markets allowed a larger number to make it to the check-out counter. I have always been astonished at the number of well-meaning socialists, whose aspirations I admire, who continue to fall for the erroneous view that controls and direct allocations are an appropriate answer to inequality.

2. But the anti-capitalist sentiments are particularly virulent among the young who arrive at their social awakening on campuses in fields other than economics. English, comparative literature and sociology are fertile breeding grounds. (15)

The Indian economist at Columbia University in the cocoon of the School of International and Public Affairs can afford to believe that the "perils of globalization" are "exaggerated" (6). He can also afford to believe that reactionary "economics" has more truth to its 
credit than English, comparative literature and sociology. Men such as Bhagwati are a part of the "categories of intellectuals" that Gramsci points out are "already in existence and which seemed indeed to represent an historical continuity uninterrupted even by the most complicated and radical changes in political and social forms" (7).

Among these intellectuals Gramsci gives the example of "ecclesiastics" who were "organically bound to the landed aristocracy. It had equal status juridically with the aristocracy, with which it shared the exercise of feudal ownership of land, and the use of state privileges connected with property." But the monopoly held by the ecclesiastics in the superstructural field was not exercised without a struggle or without limitations, and hence there took place the birth, in various forms (to be gone into and studied concretely), of other categories, favoured and enabled to expand by the growing strength of the central power of the monarch, right up to absolutism" (7). The economist Bhagwati falls among the intellectuals whose superstructural affiliations are bound with a system of privileges they benefit from. Jagadish Bhagwati's book In Defense of Globalization I would gladly use for an English class on how to write a textbook of economics or on just how to make one point in roughly 265 pages without any significant deviations.

Speaking of the "accomplishments of social medicine which have been performed in Cuba," Che says:

The principle upon which the fight against disease should be based is the creation of a robust body; but not the creation of a robust body by the artistic work of a doctor upon a weak organism; rather, 
146 | InterAção

the creation of a robust body with the work of the whole collectivity, upon the entire social collectivity.

Some day, therefore, medicine will have to convert itself into a science that serves to prevent disease and orients the public toward carrying out its medical duties.

That medicine will play the role of prevention is more or less an accepted truism. But what he calls "social medicine" is not merely about preventing disease. The "revolutionary doctor" is not just someone who prevents disease but is also part of a "revolution" because the greater disease called capitalism thrives on imperialism and what Che refers to as self-serving "individualism, in the form of the individual action of a person alone in a social milieu." He or she is involved in finding answers for the "old questions" of: "How does one actually carry out a work of social welfare? How does one unite individual endeavour with the needs of society?"

In this process of finding answers for social questions "individual goodness" that is not part of a radical cause is meaningless. The saintly doctor who selflessly works for the good of the world but locked within himself in Chekov's "The Head-Gardener's Story” might not actually be Che's idea of a revolutionary doctor. Che's doctor, like Che himself, will create the world anew in the image of a revolution. Surely he's not the protagonist of the lyrical masterpiece Dr. Zhivago by Pasternak that is deeply critical of the anti-individual nature of the revolution. Perhaps Che's physician comes closer to the utopian doctor Judym in Stefan Zeromski's novel Homeless People.

The revolutionary doctor is as much about the "revolution" as about the "doctor." In essence the discussion on revolutionary me- 
dicine moves in the direction of what Marx says in "The German Ideology." "This fixation of social activity, this consolidation of what we ourselves produce into an objective power above us, growing out of our control, thwarting our expectations, bringing to naught our calculations, is one of the chief factors in historical development up till now" (160). The revolution will overturn that "historical development" by liberating the human person from "fixation of social activity." In being a teacher, worker, farmer and politician, the revolutionary doctor demonstrates that they "are going to learn with the people."

The revolutionary doctor is what Claude Levi-Strauss calls a "bricoleur" in his book The Savage Mind.

The 'bricoleur' is adept at performing a large number of diverse tasks; but, unlike the engineer, he does not subordinate each of them to the availability of raw materials and tools conceived and procured for the purpose of the project. His universe of instruments is closed and the rules of his game are always to make do with 'whatever is at hand', that is to say with a set of tools and materials which is always finite and is also heterogeneous because what it contains bears no relation to the current project, or indeed to any particular project, but is the contingent result of all the occasions there have been to renew or enrich the stock or to maintain it with the remains of previous constructions or destructions. (11)

The collective spirit of technologically underdeveloped societies is embodied in the notion of bricolage. The doctor consciously embraces the role of a bricoleur which gives him or her plenty of opportunities to experiment with roles. In a revolutionary situation 
where time is a bigger issue than "correctness" or accuracy, to experiment is vital and everything to keep the momentum of "social change" in tact. You cannot afford to be pushed into the specialist club. The doctor is a fighter, a worker, a mother, a peasant - and everything in required proportions depending on the demands of the situation. A revolution cannot be fought in parts. The change must be holistic transformation of the social order since "there is no valid definition of socialism other than the abolition of the exploitation of one human being by another" (Global Justice 20).

Further, as Che sees it:

\begin{abstract}
We shall see that diseases need not always be treated as they are in big-city hospitals. We shall see that the doctor has to be a farmer also and plant new foods and sow, by example, the desire to consume new foods, to diversify the Cuban nutritional structure, which is so limited, so poor, in one of the richest countries in the world, agriculturally and potentially. We shall see, then, how we shall have to be, in these circumstances, a bit pedagogical- at times very pedagogical. It will be necessary to be politicians, too, and the first thing we will have to do is not to go to the people to offer them our wisdom. We must go, rather, to demonstrate that we are going to learn with the people, that together we are going to carry out that great and beautiful common experiment: the construction of a new Cuba.
\end{abstract}

Anderson in his biography of Che points out that: "For Guevara, politics were a mechanism of social change, and it was social change, not power itself, that impelled him" (177). This distinction is important to understand what revolutionary medicine is all about. 
The doctor is an agent of social change. The power that the doctor seeks is not just the power to do good, but the power to lead the masses to fight for their rights, to arouse the "nature" in a human being to "rise up" and claim "her original rights" by overturning "a corrupt political system." The doctor's role is a more immediate one as well.

And one way of getting to the heart of the medical question is not only to visit and become acquainted with the people who make up these cooperatives and work centres, but to find out what diseases they have, what their sufferings are, what have been their chronic miseries for years, and what has been the inheritance of centuries of repression and total submission. The doctor, the medical worker, must go to the core of his new work, which is the man within the mass, the man within the collectivity.

Always, no matter what happens in the world, the doctor is extremely close to his patient and knows the innermost depths of his psyche. Because he is the one who attacks pain and mitigates it, he performs and invaluable labour of much responsibility in society.

Revolutionary medicine is a multifaceted term and is about ethics as much as about politics. The ethical for Che is a manifestation at the personal level of the political. Precisely what is absent in a capitalist society is morality that does not reduce the individual to a commodity. The visible reduction into a state of a commodity is what the individual is fighting against and must eventually put to an end. Things don't happen just like that. What causes them is in many ways more important than what meets the eye. At the heart of the commodification of the individual is "imperialism" "the final stage of capitalism.” 
150 | InterAção

The contribution that falls to us, the exploited and backward of the world, is to eliminate the foundations sustaining imperialism: our oppressed nations, from which capital, raw materials and cheap labor are extracted, and to which new capital (tools of domination), arms and all kinds of goods are exported, sinking us into absolute dependence. The fundamental element of this strategic objective, then, will be the real liberation of the peoples, a liberation that will be the result of armed struggle in the majority of cases, and that, in Latin America, will almost unfailingly turn into a socialist revolution. (Global Justice 58)

Liberation is about the effective destruction of bureaucracies in the third world that take the name of "governments" and serve the interests of powerful elites. "Governments in general" says the late historian Howard Zinn in "The Uses of History and the War on Terrorism": "do not represent the people of the societies that they govern. And since they don't represent the people and since they act against the interest of the people, the only way they can hold on to power is if they lie to the people. If they told people the truth, they wouldn't last very long." This general truth applies more specifically to postcolonial nations where governments have an essentially colonial character in terms of their vicious need to preserve the status quo. The ideal response to this situation would be if only as Zinn points out: "people really knew history, if they learned history, if the educational institutions did their job, if the press did its job in giving people historical perspective, then a people would understand." History is a weapon of the revolution as much as the distortion of history through lies is the weapon of governments.

The revolutionary doctor is above all a historian and an edu- 
InterAção | 151

cator. She breaks through those imaginary cordons that ideology places in the minds of the exploited. To the oppressed she reveals the possibilities of change. She belongs to the "vanguard organization" of the "party" which is "made up of the best workers, who are proposed for membership by their fellow workers. It is a minority, but it has great authority because of the quality of its cadres. Our aspiration is for the party to become a mass party, but only when the masses have reached the level of the vanguard, that is when they are educated for communism. Our work constantly strives toward this education" (Global Justice 43).

\section{"Doctoring" the revolution}

From the perspective of "revolutionary medicine" the doctor is the bearer of the revolutionary ideal. The doctor lives the revolution as a reality. The character of the revolution is about the people and the kind of society that espouses it. Revolutions do not happen in neutral spaces. To neutralize a revolution and attempt to give it a universal character is another way of destroying it. The bourgeoisfication of the revolution is when superficial changes in lifestyles attempt to take on the character of being "radical." There is nothing radical in superficiality which is skin-deep and does not touch the mind. As Murray Bookchin puts it: "While autonomy is associated with the presumably self-sovereign individual, freedom dialectically interweaves the individual with the collective" (12). He further adds that "lifestyle anarchism" with its "trendy posturing" and "yuppie fashions" is "antithetical to the development of serious organizations, a radical 
politics, a committed social movement, theoretical coherence, and programmatic relevance" (19). It is not the lifestyle of the doctor with its self-centered individualism that will make a revolution.

The revolutionary doctor embodies the social conscience of a people and keeps the spirit of the movement alive while it seems invisible for all practical purposes. Helen Yaffe in Che Guevara - The Economics of Revolution speaks of the relationship between consciousness and social conscience. For one to be aware of the world is to be aware of the injustices that one is confronted with on a day-to-day basis and the need to address them. Interestingly Che's choice of becoming a doctor was a social choice because it meant being involved with the bodies of people. The revolutionary doctor that Che himself represents integrates an awareness of the world with a deep belief in the need to change it. To interpret the world is to change it - where each gives according to her ability and each takes as much as she needs.

Guevara's concept of consciousness as social conscience meant a commitment to the social and economic justice aims of the Revolution, the conscious integration and participation of individuals in the project of socialist transition. His concern for consciousness evolved out of his interest in philosophy, a concern for the human condition, evident through his choice of a medical career and in his observations about the social conditions he experienced travelling through Latin America in the 1950s. Human beings were central to his vision of history and social development. Like Marx, he was interested not only in the historical development of modes of production, but also their impact on human beings as the key to production. (231-32) 
Any revolution has both immediate as well as long-term goals and both need not always seem compatible for the sake of consistency. The dismantling of colonial structures is a painfully slow process because it entails changing the mindset before eliminating the forms that this mindset requires for its sustenance just as a ghost needs a body for it to act with the full force of its evil; exorcizing the ghost of colonialism is the goal of a revolution in the third world. The "liberation" that comes with globalization is restricted to lifestyles without any social content; the liberation that comes with a revolution brings out the collective character of the individual and the individual character of the collective. It shows that they're inseparable and therefore any personal liberation is political in the larger sense of the term involving the 'body politic.' In any revolutionary context "truth" and "social justice" are terms that mean one and the same thing which is the liberation of the exploited.

For all its limitations the nationalization of healthcare is a priority in a democratic political system. Politically this is the maximum that can be achieved in a system based on electoral politics but not of course without a mass movement in that direction. A modern, educated elite which aspires to produce alternatives to a social revolution would not mind considering nationalization as a viable alternative to western-style corporatization whose viciousness is bound to provoke an equally harsh response from the victims of a corporate order. The nationalization of medicine will not change the reactionary attitudes of medical personnel used to looking at the patient as a dependent. A transformation of attitudes cannot be achieved except through a revolution. 
The nationalization of medicine is the buffer period before the revolution. A revolution is essentially a period of cautious waiting without apparently doing much or what Gramsci terms as "intransigence." The movement takes on an "intellectual" character. Like Aristotle's definition of God as the "unmoved mover," the revolution moves to raise the class consciousness of a people while keeping its intransigent position. "Movement, however, is never just a physical act; it is intellectual as well. Indeed, it is always intellectual before becoming physical - except for puppets on a string" (The Gramsci Reader 44). The revolution must happen in the mind before it shows itself in physical terms. The time that will cancel every other time is the time of the revolution. It is also the time of the poet and the prophet. The time of the revolutionary is Che Guevara hounded to death in the jungles of Bolivia; a man who "did not simply theorize about guerrilla warfare; he practiced it from the triumph of the Cuban Revolution on January 1, 1959, to his death in Bolivia on October 9, 1967" (Dosal 183).

A socialist state should not face constraints in viewing the nationalization of medicine as an immediate goal. It's the first step in the long process of revolutionizing medicine in a way that will root the doctor within the framework of ethical responsibility and give the patient the right to evaluate the doctor. The body's privacy is a sensitive issue; because social life depends on how the body is able to stand up for itself at home, the workplace and the street; the hospital that has access to the patient's body must show extraordinary compassion to combat the sense of isolation that he or she experiences in the context of the "treatment." The patient's body is not an actor in a 
porn-film with mechanically driven responses. The body that is "ill" is filled with a genuine love of life. The goals of medicine cannot be independent of the goals of life. As Cassell points out in The Nature of Suffering and the Goals of Medicine

Central to any moral understanding is the concept of person. Ethical standards; rules about good and bad, right and wrong; rights and their corollary obligations; matters of custom and conscience that guide the moral aspects of life are always in terms of persons (even though they may be directed toward nonhuman matters, such as animals or the environment). It follows that all understandings of the moral and morality are based on some idea of the nature of persons, whether manifest or latent. (Cassell 26)

The goals of medicine must be compatible with those of a just and egalitarian society. Johnson says that "A decent provision for the poor is the true test of civilization" (329). A true test of civilization is how we care for the poor and the powerless. Civilization is how we "look" at the sick, how we define what is normal and how we feel about the dying. The "true test" is in recognizing the personhood of the person. The reality of the person is central to any notion of civilization that must be rescued from its colonial overtones. Such a notion of civilization has to be a revolutionary one. A revolution is built with the centrality of the person in mind. Without a person to substantiate it a revolution is an empty term. A social revolution embraces the body of the marginalized - the body abandoned to the streets by the global order. Health is a meaningful concept when it fights for the rights of the sick. To 
be healthy is a passive state. To be health conscious is a bourgeois contempt for work-related activity. Health in its political state is a moral understanding of the body.

Reforms that create a small number of beneficiaries out of a sea of deprived masses will perpetuate the framework of an exploitative order. That's where socialism as the basis of decolonization comes into the picture. As Nkrumah says: "Whereas capitalism is a development by refinement from slavery and feudalism, socialism does not contain the fundamental ingredient of capitalism, the principle of exploitation" (Decolonization 73). Decolonization is the process as much as it is the goal of all postcolonial societies. It does not happen in a piecemeal "reformist" manner. To quote Nkrumah "The passage from the ancestral line of slavery via feudalism and capitalism to socialism can only lie through revolution: it cannot lie through reform” (Decolonization 73).

Revolution is the antidote to global injustice perpetuated through capitalism. The revolutionary doctor's relationship with the sick is not constructed around power since revolutions are ultimately about faith and believers and not about logic and philosophers of logic. It's a faith guided by a scientific rationale because it is based on the experiences of real men and women on the ground. The "truth" of science is not fundamentally different from the truth of revolutions. Both rely on experience to make the final decision. The revolutionary doctor is as much a revolutionary as a doctor. His or her relationship with the sick is based on shared humanity and the long-term goal of social change. The lines that Che thought as a boy on a motorcycle journey across Latin America stand true now as ever before: 
InterAção | 157

Like the medical researcher he was on his way to becoming, Ernesto immediately searched for a cause when he saw a symptom. And, having found what he thought was the cause, he searched for its antidote. Thus, in Ernesto's mind, the dying old lady in Valparaiso and the persecuted miner couple on the road to Chiqui had become "living examples of the proletariat in the whole world," who lived in misery because of an unjust social order, and whose lives would not improve until future enlightened governments changed the state of things. Symptom and cause were wrapped up into one ugly package. Standing behind the local regimes holding sway and perpetuating the injustice were the Americans and their overwhelming economic power. (ARL 82)

If revolutions are built on faith based on reasons that experience gives them, "self-sacrifice" and "solidarity" form the moral basis of the change. While pointing out that, "All our knowledge has its origin in our perceptions" (6), Da Vinci adds that "all sciences are vain and full of errors that are not born of Experience, mother of all certainty, and that are not tested by Experience; that is to say, that do not at their origin, middle, or end, pass through any of the five senses" (6). The scientific character of revolutions is based on experience and faith in the observations produced by experience. A transformed society is the end result of the faith because it brings with it a new set of attitudes that does not revolve around profit-making or individual gain. As Helen Yaffe says:

For Guevara, the challenge was to replace alienation and antagonism with integration and solidarity, developing a collective attitude to production and the concept of work as a social duty...As so- 
158 | InterAção

cialist consciousness developed and workers took increasing control of production, they would value increases in production and productivity, not in terms of personal gain or profit, but as increasing the benefits for society. Work would evolve from a social duty into a social pleasure. (232)

The "social pleasure" in how one takes real joy in sharing one's knowledge with the world is at its greatest in the case of the doctor. In a way the state of healthcare is a litmus test for how society is doing. To diagnose the ills of a social order we need to see the level of health in that particular order. The doctor is a revolutionary before he or she is a doctor. Being a doctor is an acknowledgement of one's role in the processes of social transformation.

In the absence of a corporate framework where the doctor is an authority-figure that one needs to look up to, the patient is a friend who opens the possibilities for a deeper understanding of the human body. The doctor cannot play the role of the savior. His knowledge plays a partial role in providing an understanding of the complexities of human life. The physicist and mathematician Freeman Dyson points out: "Life has escaped the tyranny of the genes by evolving brains with neural connections that are not genetically determined. The detailed structure of the brain is partly shaped by genes and environment and is partly random" (89). The tyranny of man over others goes against the nature of living because it tries to suppress that which is random and creative in a person. The partiality in our attempts to know the world has to be acknowledged in order to reduce the kind of institutional power that doctors are endowed with. Since this power does not work in isolation but is connected to the power 
that capitalism invests in the global market system my thesis is that it is not possible to dismantle the corporate-based medical industry without a social revolution in view.

\section{BIBLIOGRAPHY}

ANDERSON, Jon Lee. Che Guevara - A Revolutionary Life. New York: Grove Press, 1997.

BENJAMIN, Walter. The Work of Art in the Age of Mechanical Reproduction. 1936. Walter Benjamin Archive. Web. Feb. 2005.

BHAGWATI, Jagdish. In Defense of Globalization. New York: Oxford University Press, 2004.

BLAKE, William. The Marriage of Heaven and Hell. 1790-93. The Alchemy Website. 7 May 1995.

BOOKCHIN, Murray. Social Anarchism or Lifestyle Anarchism: an unbridgeable chasm. Edinburgh and San Francisco: AK Press, 1995.

BOSWELL, James. The Life of Samuel Johnson. London: Penguin, 2008.

CASSELL, Eric. J. The Nature of Suffering and the Goals of Medicine. New York and Oxford: Oxford University Press, 1994.

DUARA, Prasenjit. Decolonization - Perspectives from Now and Then. London and New York: Routledge, 2004.

DOSAL, Paul J. Comandante Che. University Park: The Pennsylvania State University Press, 2003. 
160 | InterAção

DYSON, Freeman. Origins of Life. Cambridge: Cambridge University Press, 2004.

FORGACS, David. The Gramsci Reader - Selected Writings 1916-1935. New York: New York University Press, 2000.

GRAMSCI, Antonio. Prison Notebooks. ed. and trans. Hoare, Quentin and Geoffrey Nowell Smith. New York: International Publishers, 1992.

GUEVARA, Che. Che Guevara Internet Archive. Marxists Internet Archive Library. January 28, 2012. < http://www.marxists.org/archive/ guevara/works.htm>. Global Justice: Liberation and Socialism. Delhi: LeftWord Books, 2004.

Health Reform and the Department of Health and Human Services. January 28, 2012. <http://www.healthreform.gov/health_reform_and_ hhs.html>.

KOSIK, Karel. Dialectics of the Concrete. Dordrecht-Holland: D. Reidel Publishing Company, 1976.

VINCI, Leonardo da. Notebooks. Oxford: Oxford University Press, 2008.

MCMURTRY, John. The cancer stage of capitalism. London: Pluto Press, 1999.

Munna Bhai MBBS. Dir. Rajkumar Hirani. Vinod Chopra Productions, 2003. Film.

ORWELL, George. How the poor die. Web. January 28, 2012.

Poverty in India, Economy Watch. Web. January 28, 2012. 
InterAção | 161

Rajiv Aarogyasri Community Health Insurance Scheme. January 28, 2012. <http://www.aarogyasri.org/>

LOUISE, Robbins. E. Louis Pasteur and the hidden world of microbes. Oxford: Oxford University Press, 2001.

TUCKER, Robert C. Ed. The Marx-Engels Reader. New York: Norton, 1978.

YAFFE, Helen. Che Guevara - The Economics of Revolution. New York: Palgrave Macmillan, 2009.

ZINN, Howard. The uses of history and the war on terrorism, Web. Nov. 24, 2006. 
162 | InterAção 